\title{
Effects of Mechanical Processing on the Nutritive Value of Barley Silage for Lactating Dairy Cows*
}

\author{
J.-S. Eun, ${ }^{1}$ K. A. Beauchemin, ${ }^{1}$ S.-H. Hong, ${ }^{2}$ and W. Z. Yang \\ ${ }^{1}$ Agriculture and Agri-Food Canada, Research Centre, Lethbridge, AB, Canada T1J 4B1 \\ ${ }^{2}$ Department of Animal Science, Sahmyook College, Seoul, Korea
}

\begin{abstract}
Mechanical processing of whole crop barley before ensiling may be useful for improving nutrient use by dairy cattle. The objective of this study was to assess the effects of feeding mechanically processed barley silage as the main forage source on lactational performance. Twenty-four Holstein cows, 16 primiparous (187 \pm 52 days in milk) and 8 multiparous ( $87 \pm 69$ days in milk) cows, were used in a completely randomized design with a 2 -wk covariate period and a 6 -wk treatment period. The 2 treatments were: 1) total mixed ration (TMR) containing regular barley silage (RBS-TMR), and 2) TMR containing mechanically processed barley silage (MPBS-TMR). Barley silage and alfalfa hay supplied 41 and $5 \%$ of the dietary dry matter (DM), respectively. Intake, body weight, and milk production were measured during the covariate and treatment periods. In addition, 2 multiparous cows were used for in situ measurements of the ruminal DM and fiber degradation kinetics of the barley silages and TMR. Data were analyzed with repeated measurements using a mixed model that included the covariate adjustment. Feeding MPBS-TMR had no significant effects on DM intake (DMI; $21.7 \mathrm{~kg} / \mathrm{d})$, milk yield ( $33.9 \mathrm{~kg} / \mathrm{d})$, or milk composition, with only $4 \%$ FCM (fat-corrected milk) yield (29.7 vs. $31.7 \mathrm{~kg} / \mathrm{d}$ ) and milk fat concentration ( $3.30 \mathrm{vs} .3 .57 \%$ ) showing a numerical improvement. Apparent digestibilities of DM and nutrients were not affected by feeding MPBS-TMR, with the exception of starch digestibility, which tended to increase. Dairy efficiencies calculated as milk yield/DMI or FCM/DMI were not different between treatments. Body weight and body condition score were not affected by treatments. Effective ruminal degradability of DM was similar for both barley silages, indicating that when the silages were ground to remove the effects of mechanical processing, the po-
\end{abstract}

Received July 15, 2004.

Accepted September 9, 2004.

Corresponding author: Karen A. Beauchemin; e-mail: beauchemin @agr.gc.ca.

*Contribution number (387) 04052 of the Lethbridge Research Centre. tential digestion was similar. Mechanical processing of barley silage harvested at a mid-dough stage of maturity resulted in small improvements in its nutritive value for lactating dairy cows and had minor impact on digestibility and milk production.

(Key words: mechanically processed forage, barley silage, digestibility, milk production)

Abbreviation key: ERD = effective ruminal degradability, MPBS = mechanically processed barley silage, MPBS-TMR = TMR containing mechanically processed barley silage, pef $=$ physical effectiveness factor RBS = regular barley silage, RBS-TMR = TMR containing regular barley silage.

\section{INTRODUCTION}

Quality of forages for ruminants is mainly affected by maturity and moisture at harvest, method of preservation, type of storage structure, and feeding management. Mechanical kernel processing systems for forage crops are becoming more common in North America. These systems are intended to process corn plants at the time of cutting before ensiling to ensure kernel damage and improve starch use in ruminants (Johnson et al., 1999). Mechanical processing generally consists of 2 rollers in the silage harvester between which the chopped material must pass. The rollers crush and shear the material as it passes through, fracturing the corn kernels and crushing the corn stover. Fracturing the corn kernels in corn silage has been shown to improve starch digestibility (Bal et al., 2000; Weiss and Wyatt, 2000), and crushing and shearing the stover fraction enhanced NDF digestibility (Johnson et al., 2002). Results from Bal et al. (2000) indicated that cows fed diets containing processed corn silage harvested at 3 chop lengths $(0.95,1.45$, and $1.90 \mathrm{~cm})$ increased DMI, milk production, and milk fat concentration compared with cows fed diets containing unprocessed corn silage harvested at $0.95 \mathrm{~cm}$. The results could be due to increased ruminal and total tract starch digestibility by mechanical processing of corn silage. On the other hand, Weiss and Wyatt (2000) reported increased starch digestibility and a tendency $(P<0.07)$ for in- 
creased milk fat percentage when cows were fed mechanically processed corn silage, but DMI and milk production were not affected.

Although a wide variety of forage crops are successfully used in dairy production systems, barley silage is the main forage component for dairy cow diets in western Canada. Barley silage is typically harvested in an early to mid-dough stage of maturity, allowing the crop to be ensiled at about 30 to $40 \% \mathrm{DM}$ (Baron et al., 2000). With advancing maturity, digestibility of the forage crop declines due to maturation of the hull, which provides a physical barrier to digestion of the whole kernel. Barley silage, like most small cereal silages, has a high proportion of rumen-fermentable carbohydrates such as starch. Mechanical processing of the barley crop before ensiling may disrupt the physical barriers and increase the surface area for digestion by microbial or host enzymes. Therefore, we hypothesized that an improvement in digestibility and milk production could occur if cows were fed mechanically processed barley silage (MPBS). The objective of this study was to determine the effects of feeding MPBS as the main forage source on digestibility and lactational performance of dairy cows.

\section{MATERIALS AND METHODS}

\section{Animals and Diets}

The experiment was carried out using 24 Holstein cows consisting of 16 primiparous and 8 multiparous cows in midlactation. At the start of the experiment, DIM averaged $187 \pm 52$ and $87 \pm 69$ for primiparous and multiparous cows, respectively. Average BW was $654 \pm 67 \mathrm{~kg}$ at the beginning of the experiment and 659 $\pm 61 \mathrm{~kg}$ at the end of the experiment.

Barley (semidwarf cultivar, Duke) was grown under irrigation near Lethbridge, $\mathrm{AB}$, Canada. The crop received recommended amounts of fertilizer based on soil tests. The whole plant was harvested in a mid-dough stage of maturity in August 2002. Half of the material was left unprocessed, and the other half was mechanically processed during harvesting. A theoretical chop length of $0.95 \mathrm{~cm}$ was used in both cases. The mechanical processing was done using an automatic roller mill (Jaguar 900 model, Claas Ltd., Hansewinkel, Germany) designed for processing of corn plants, which was attached to the forage harvester. The rollers were adjusted to the smallest possible setting with 1-mm clearance. Both silages were stored in separate silo bags.

The experiment was conducted as a completely randomized design with covariate and treatment periods for a total of $56 \mathrm{~d}$. For the first $2 \mathrm{wk}$, all cows received a TMR containing regular barley silage (RBS). This 2wk phase was used as the covariate period, thus milk
Table 1. Ingredients and chemical composition of the experimental diets.

\begin{tabular}{lcc}
\hline & \multicolumn{2}{c}{ Diets $^{1}$} \\
\cline { 2 - 3 } Item & RBS-TMR & MPBS-TMR \\
\hline Ingredient, \% of DM & & \\
Barley silage, regular & 41.2 & - \\
Barley silage, mechanically processed & 5.4 & 51.2 \\
Alfalfa hay, chopped & 7.7 & 7.7 \\
Corn, dry rolled & 6.1 & 6.1 \\
Barley, ground & 0.2 & 0.2 \\
Corn, ground & 9.0 & 9.0 \\
Alberta Gold & 5.2 & 5.2 \\
Beet pulp, ground & 8.9 & 8.9 \\
Soy Pass ${ }^{3}$ & 7.4 & 7.4 \\
Corn gluten meal & 2.8 & 2.8 \\
Molasses beet & 0.8 & 0.8 \\
Limestone & 1.2 & 1.2 \\
Dicalcium phosphate & 0.7 & 0.7 \\
Sodium bicarbonate & 0.02 & 0.02 \\
Anise & 2.4 & 2.4 \\
Canola oil & 1.1 & 1.1 \\
Mineral and vitamin premix & & \\
Chemical composition, ${ }^{6} \%$ of $^{4}$ DM & & \\
DM, \% & $57.2 \pm 1.0$ & $55.3 \pm 0.8$ \\
OM & $92.0 \pm 0.1$ & $92.4 \pm 0.1$ \\
CP & $18.5 \pm 0.1$ & $18.7 \pm 0.1$ \\
NDF & $30.7 \pm 0.4$ & $29.5 \pm 0.3$ \\
ADF & $15.9 \pm 0.3$ & $14.2 \pm 0.1$ \\
Starch & $29.5 \pm 0.5$ & $31.4 \pm 1.3$ \\
\hline
\end{tabular}

${ }^{1}$ RBS-TMR = TMR containing regular barley silage; MPBS-TMR = TMR containing mechanically processed barley silage.

${ }^{2}$ Alberta Gold is a heat-processed canola meal product (Canbra Foods, Lethbridge, AB, Canada).

${ }^{3}$ Soy Pass is a nonenzymatic browned, dehulled solvent extract soybean meal product (LignoTech USA, Inc., Rothschild, WI).

${ }^{4}$ Anise is a flavoring agent (Canadian Bio-systems Inc., Calgary, $\mathrm{AB}$, Canada).

${ }^{5}$ Contained $29.4 \% \mathrm{NaCl}, 1.0 \% \mathrm{ZnSO}_{4}, 1.2 \% \mathrm{MnSO}_{4} \cdot 4 \mathrm{H}_{2} \mathrm{O}, 0.4 \%$ $\mathrm{CuSO}_{4} \cdot 5 \mathrm{H}_{2} \mathrm{O}, 45 \mathrm{mg} / \mathrm{kg} \mathrm{CoSO}{ }_{4} \cdot 5 \mathrm{H}_{2} \mathrm{O}, 44 \mathrm{mg} / \mathrm{kg} \mathrm{Na}{ }_{2} \mathrm{SeO}_{3}, 8 \%$ Dynamate (Pitman Moore, Inc., Mundelein, IL; $22 \% \mathrm{~S}, 18 \% \mathrm{~K}$, and $11 \%$ $\mathrm{Mg}), 60 \mathrm{mg} / \mathrm{kg}$ of ethylenediamine dihydroiodide, $680 \mathrm{IU}$ of vitamin $\mathrm{A} / \mathrm{g}, 160 \mathrm{IU}$ of vitamin D/g, and $2 \mathrm{IU}$ of vitamin $\mathrm{E} / \mathrm{g}$.

${ }^{6}$ Values were obtained from chemical analysis of TMR samples.

yield, milk composition, and DMI were determined. At the end of the covariate period, cows were divided into 2 groups, each with 12 animals, similar in milk yield $(34.7 \pm 8.0$ and $35.1 \pm 8.0 \mathrm{~kg} / \mathrm{d})$ and DMI $(21.1 \pm 2.2$ and $22.2 \pm 3.6 \mathrm{~kg} / \mathrm{d}$ ) and allocated to 1 of 2 treatment diets. Equal numbers of multiparous and primiparous cows were assigned to each treatment diet. The 2 treatment diets were: 1) TMR containing RBS (RBS-TMR), and 2) TMR containing (MPBS) (MPBS-TMR) (Tables 1 and 2). The RBS-TMR was the same diet that was fed to the cows during the covariate period. Diets were formulated to sustain $35 \mathrm{~kg} / \mathrm{d}$ of milk production with $3.5 \%$ of fat and $3.3 \%$ of CP using the Cornell-PennMiner System (CPM Dairy, Version 2.0), a computer program based on the Cornell Net Carbohydrate and Protein System principles (Sniffen et al., 1992). 
Table 2. Chemical composition of forages.

\begin{tabular}{llll}
\hline & \multicolumn{3}{c}{ Forage $^{1}$} \\
\cline { 2 - 4 } Item & RBS & MPBS & Alfalfa hay \\
\hline DM, \% & $39.7 \pm 0.7$ & $37.2 \pm 1.1$ & $90.6 \pm 1.6$ \\
OM, \% of DM & $90.1 \pm 0.3$ & $91.4 \pm 0.1$ & $90.8 \pm 0.1$ \\
CP, \% of DM & $12.8 \pm 0.1$ & $12.9 \pm 0.1$ & $13.7 \pm 0.3$ \\
NDF, \% of DM & $38.7 \pm 0.6$ & $37.3 \pm 0.1$ & $53.2 \pm 0.4$ \\
ADF, \% of DM & $20.8 \pm 0.2$ & $20.0 \pm 0.1$ & $38.2 \pm 0.2$ \\
Starch, \% of DM & $24.6 \pm 0.8$ & $24.3 \pm 0.7$ & ND $^{2}$ \\
\hline
\end{tabular}

${ }^{1} \mathrm{RBS}=$ Regular barley silage; MPBS = mechanically processed barley silage.

${ }^{2} \mathrm{ND}=$ Not determined.

Diets were fed as a TMR for ad libitum intake with at least $10 \%$ of daily feed refusal. All cows were individually fed 3 times daily at 0600,1400 , and $1800 \mathrm{~h}$ with approximately 10,50 , and $40 \%$ of total daily feed allocation, respectively. Cows had free access to water. Intake and milk production were recorded daily throughout the experiment.

Cows were cared for according to the Canadian Council on Animal Care guidelines (Ottawa, ON, Canada). Cows were housed in individual tie stalls fitted with rubber mattresses and bedded with wood shavings, and were milked twice daily at 0630 and $1630 \mathrm{~h}$. They were turned outside in a dry-lot for exercise for at least $1 \mathrm{~h}$ daily in the morning after being milked.

Barley silages, chopped alfalfa hay, and concentrates were sampled weekly to determine DM content. Diets were adjusted weekly to account for changes in DM content. Samples of the barley silages and TMR fed were collected daily and composited weekly. Part of the weekly composited samples was saved for determining particle size distributions, and the rest were dried at $55^{\circ} \mathrm{C}$, ground to pass a $1-\mathrm{mm}$ screen (standard model 4; Arthur H. Thomas Co., Philadelphia, PA), and stored for subsequent analyses.

Particle size distributions of barley silages and TMR were measured by sieving using the Penn State Particle Separator (Lammers et al., 1996). The sum of the DM retained on the top and middle sieves was assumed equal to the physical effectiveness factor (pef) of feeds.

Milk was sampled on 2 consecutive days during the a.m. and p.m. milkings in each week throughout the experiment. Milk samples were preserved with potassium dichromate and stored at $4^{\circ} \mathrm{C}$ until sent to the Central Alberta Milk Testing Laboratory (Edmonton, $\mathrm{AB}$, Canada). Milk was analyzed for fat, protein, and lactose (AOAC, 1990) using an infrared analyzer (MilkO-Scan 605; Foss Electric, Hillerød, Denmark). Milk composition was corrected for differences in milk volume between the a.m. and p.m. milkings.

Mean BW of cows was calculated by weighing the cows weekly during the experiment at approximately
$1300 \mathrm{~h}$. Body condition score, ranging from 1 (thin) to 5 (obese), was recorded at the beginning and end of the covariate and the treatment periods according to the method of Wildman et al. (1982).

\section{Digestibility}

Apparent digestibilities of DM and nutrients in the total tract were determined using chromium as an external marker for the last $3 \mathrm{wk}$ during the treatment period. Approximately $2.92 \mathrm{~g}$ of $\mathrm{Cr}_{2} \mathrm{O}_{3}$ (equivalent to 2 $\mathrm{g}$ of $\mathrm{Cr}$ ) diluted using ground barley was top-dressed daily onto the feed at the p.m. feeding for 19 consecutive days. To ensure the cows consumed the entire marker each day, it was allocated as follows. Immediately after the orts were removed from the feeder, a small amount of TMR (approximately $1 \mathrm{~kg}$ ) and the top-dressed marker were placed in front of the cows. Once the marker was consumed in its entirety, the additional TMR was allocated to the cows. After $7 \mathrm{~d}$ of dosing, fecal samples (approximately $100 \mathrm{~g}$ ) were taken from the rectum of each cow once or twice daily at various times for the last $12 \mathrm{~d}$. The fecal samples were pooled by individual cow, dried at $55^{\circ} \mathrm{C}$, and ground to pass a 1-mm screen (Intermediate mill, Arthur H. Thomas Co.) for chemical analysis. Chromium was assumed to be completely indigestible and the digestibility of DM was calculated using the following equation: DM digestibility $=1-[\mathrm{Cr}$ fed $(\mathrm{mg} / \mathrm{d}) / \mathrm{DMI}(\mathrm{kg} / \mathrm{d})] / \mathrm{Cr}$ in feces $(\mathrm{mg} / \mathrm{kg}$ of DM), where DMI was the average of DM consumed on the days that fecal samples were collected. Digestibility of nutrients was calculated using the same approach.

\section{In Situ Measurements}

Two multiparous cows were used for in situ measurements of the ruminal DM degradation kinetics of RBS, MPBS, RBS-TMR, and MPBS-TMR. The feeds were processed before incubation, thus the purpose of the in situ measurements was to verify whether the rate and extent of digestion was the same for both treatments once the physical differences between treatments were removed. Fresh barley silages and TMR were chopped for 5 s using a Knifetec 1095 sample mill (Foss Tecator, Höganäs, Sweden). Five grams of samples (as-fed) were weighed into bags $(10 \times 20 \mathrm{~cm})$ made of monofilament PeCAP polyester screen (pore size, $51 \pm 2 \mu \mathrm{m}$; B. \& S. H. Thompson, Ville Mont-Royal, QC, Canada). Bags were heat-sealed and placed in large $(20 \times 30 \mathrm{~cm})$ mesh retaining sacs with $3-\times 5$-mm pores that permitted ruminal fluid to percolate freely. Triplicate nylon bags were placed in the rumen for $0,3,6,9,12,24,48$, 72 , and $96 \mathrm{~h}$. Upon removal, bags were washed under 
running tap water until the effluent was clear and then were dried at $55^{\circ} \mathrm{C}$ for $48 \mathrm{~h}$. Bags and contents were weighed for the calculation of DM disappearance, and residues were ground to pass a 1-mm screen and stored for the analysis of fiber.

\section{Chemical Analysis}

Feed DM was determined by oven drying at $55^{\circ} \mathrm{C}$ for $48 \mathrm{~h}$. Analytical DM content of the samples was determined by drying at $135^{\circ} \mathrm{C}$ for $3 \mathrm{~h}$ (AOAC, 1990). Organic matter content was calculated as the difference between $\mathrm{DM}$ and ash contents, with ash content determined by combustion at $550^{\circ} \mathrm{C}$ overnight. For the measurement of $\mathrm{CP}(\mathrm{N} \times 6.25)$, samples were ground using a ball mill (Mixer Mill MM2000; Retsch, Haan, Germany) to a fine powder. Nitrogen was quantified by flash combustion with gas chromatography and thermal conductivity detection (Carlo Erba Instruments, Milan, Italy). Chromium was determined by inductively coupled plasma emission spectrometry (SpectoCi$\operatorname{ros}^{\mathrm{CCD}}$, Specto Analytical Instruments, GmbH \& Co., Kleve, Germany) after dry ashing at $550^{\circ} \mathrm{C}$ for $5 \mathrm{~h}$ and extraction of $\mathrm{Cr}$ according to the method of Williams et al. (1962), but dilution after digestion of sample was done with only water instead of adding calcium chloride. Neutral detergent fiber and $\mathrm{ADF}$ were determined in the $\mathrm{ANKOM}^{200}$ Fiber Analyzer (ANKOM Technology Corp., Fairport, NY) using heat-stable $\alpha$-amylase and sodium sulfite. Starch content of feed and feces was determined by a 2 -step enzymatic method (Rode et al., 1999 ) with a microtiter plate reader (Dynatech Laboratories, Chantilly, VA) to read glucose release colorimetrically at $490 \mathrm{~nm}$.

\section{Statistical Analysis}

Kinetics of DM degradation in situ was estimated by the nonlinear regression procedure of SAS (SAS Institute, 2001). For each cow and type of feed, the following model (Ørskov and McDonald, 1970) was fitted to the percentage of DM degradation:

$$
y=a+b\left(1-e^{-c(t-L)}\right) \text { for } t>L,
$$

where $\mathrm{a}=$ soluble fraction (percentage), $\mathrm{b}=$ slowly degradable fraction (percentage), $\mathrm{c}=$ rate of degradation (per hour), $\mathrm{L}=$ lag time (hours), and $\mathrm{t}=$ time of incubation (hours).

Effective ruminal degradability (ERD) of DM was estimated using the following equation (Ørskov and McDonald, 1970):

$$
\mathrm{y}=\mathrm{a}+\mathrm{b} \times \mathrm{c} /(\mathrm{c}+\mathrm{k})
$$

where $\mathrm{k}=$ rate of particulate passage (assumed to be 2.8 and $4.0 \% / \mathrm{h}$ for barley silage and TMR, respectively).

Daily intake, milk yield, and milk composition values were reduced to weekly means before data analysis. Data for DMI, BW, and milk yield obtained during the covariate period were used as covariates for the corresponding measurements during the treatment period. ANOVA was conducted using the Proc Mixed procedure of SAS (SAS Institute, 2001) for a completely randomized design with repeated measures. The model included the effects of treatment, week, and the interaction between treatment and week, with the random variable being the cow within treatment. Simple, autoregressive one, and compound symmetry covariance structures were used in the analysis depending on low values for the Akaike's information criteria and Schwartz's Bayesian criterion. Least square means are reported throughout. Treatment effects were declared significant at $P<0.05$ and trends were discussed at $P$ $<0.15$ unless otherwise noted.

\section{RESULTS AND DISCUSSION}

There was little difference in chemical composition between RBS and MPBS (Table 2), suggesting that processing did not affect nutrient composition of barley silage. Barley silage typically contains 48 to $60 \%$ of $\mathrm{NDF}, 29$ to $37 \%$ of $\mathrm{ADF}$, and 12 to $14 \%$ of starch in the DM (Khorasani et al., 1993; Yang et al., 1997; Mustafa et al., 2000). The NDF (38\%) and ADF (20\%) concentrations of the barley silages used in this study were considerably lower, and starch concentration of the barley silage (24\%) was higher than those reported in the literature for silages of similar maturity. In cereal silage, grain content may vary substantially. Baron et al. (1992) reported that barley grain content could range from 30 to $43 \%$ and from 37 to $52 \%$ at 30 and $35 \%$ of silage DM, respectively, implying that the grain content of barley may vary depending upon different stages of plant development and moisture contents at harvest. In addition, a semidwarf type of barley such as the Duke cultivar used in this study typically has lower fiber levels, higher grain content, and higher in vitro digestible OM than other barley types (Baron et al., 2000). The low fiber concentrations of the barley silages used in this study likely resulted from a dilution effect on whole plant fiber content caused by increased grain content and resultant increased starch concentration.

Analysis of particle size indicated that MPBS had a slightly lower proportion retained on the top screen compared with RBS (Table 3). Overall, mechanical processing of barley silage caused minimal changes in particle length, and the pef of both silages were similar. 
Table 3. Particle size distribution and physical effectiveness factor of barley silages and TMR determined by the Penn State Particle Separator.

\begin{tabular}{|c|c|c|c|c|}
\hline \multirow[b]{2}{*}{ Item } & \multicolumn{2}{|c|}{ Barley silage $^{1}$} & \multicolumn{2}{|c|}{$\mathrm{TMR}^{2}$} \\
\hline & RBS & MPBS & RBS-TMR & MPBS-TMR \\
\hline \multicolumn{5}{|c|}{ DM retention on sieve, $\%$} \\
\hline Top, $19 \mathrm{~mm}$ & $4.92 \pm 0.21$ & $2.87 \pm 0.13$ & $8.68 \pm 0.07$ & $4.07 \pm 0.08$ \\
\hline Middle, $8 \mathrm{~mm}$ & $71.1 \pm 0.8$ & $70.5 \pm 0.2$ & $35.4 \pm 1.6$ & $32.9 \pm 0.6$ \\
\hline Bottom & $24.0 \pm 0.6$ & $26.6 \pm 0.3$ & $55.9 \pm 1.6$ & $63.0 \pm 0.7$ \\
\hline pef $^{3} \%$ & $76.0 \pm 0.6$ & $73.4 \pm 0.3$ & $44.1 \pm 1.6$ & $37.0 \pm 0.7$ \\
\hline
\end{tabular}

${ }^{1} \mathrm{RBS}=$ Regular barley silage; MPBS = mechanically processed barley silage.

${ }^{2}$ RBS-TMR = TMR containing regular barley silage; MPBS-TMR = TMR containing mechanically processed barley silage.

${ }^{3}$ pef $=$ Physical effectiveness factor determined as the portion of DM retained by top and middle sieves of the Penn State Particle Separator.

The same trend was observed for particle distributions of the diets.

Intakes of $\mathrm{DM}$ and $\mathrm{OM}$ did not differ between treatments (Table 4). The lack of effect of feeding MPBS on DMI was consistent throughout the experiment (Figure 1). Although there were no differences in intakes of starch, NDF, or $\mathrm{N}$ between treatments (Table 4), cows fed the MPBS-TMR had lower ADF intake than those fed the RBS-TMR, due to lower concentration of ADF in the MPBS-TMR than the RBS-TMR (14.2 vs. 15.9\%, Table 1). The ratio of starch to NDF intake increased in cows fed the MPBS-TMR compared with cows fed the RBS-TMR due to numerically higher intake of starch and numerically lower intake of NDF in cows fed the MPBS-TMR.

Digestibility of DM averaged $60.2 \%$, and did not differ between treatments (Table 4). Similarly, digestibilities

Table 4. Intake and total tract digestibility of DM and nutrients by dairy cows fed regular or mechanically processed barley silage.

\begin{tabular}{lcccr}
\hline & \multicolumn{3}{c}{ Diets $^{1}$} & \\
\cline { 2 - 3 } Item & RBS-TMR & MPBS-TMR & SE & $P$ \\
\hline Intake, kg/d & & & & \\
DM & 21.8 & 21.5 & 0.4 & 0.64 \\
Digestible DM & 12.5 & 13.2 & 0.4 & 0.18 \\
OM & 19.7 & 20.2 & 0.9 & 0.70 \\
Starch & 6.32 & 6.87 & 0.30 & 0.21 \\
ADF & 3.41 & 3.10 & 0.11 & 0.05 \\
NDF & 6.65 & 6.27 & 0.28 & 0.35 \\
N & 0.63 & 0.66 & 0.02 & 0.51 \\
Starch/NDF & 0.95 & 1.10 & 0.01 & $<0.01$ \\
Digestibility, \% & & & & \\
DM & 59.6 & 60.7 & 1.3 & 0.54 \\
OM & 63.0 & 63.9 & 1.3 & 0.62 \\
Starch & 93.5 & 94.3 & 0.4 & 0.15 \\
ADF & 25.0 & 22.0 & 2.5 & 0.41 \\
NDF & 31.4 & 31.6 & 2.4 & 0.95 \\
N & 59.0 & 61.0 & 1.6 & 0.37 \\
\hline
\end{tabular}

${ }^{1} \mathrm{RBS}-\mathrm{TMR}=\mathrm{TMR}$ containing regular barley silage; $\mathrm{MPBS}-\mathrm{TMR}=$ TMR containing mechanically processed barley silage.

${ }^{2}$ Ratio of starch to NDF intake. of $\mathrm{OM}, \mathrm{ADF}, \mathrm{NDF}$, and $\mathrm{N}$ did not differ between treatments. Although feeding the MPBS-TMR tended $(P=$ $0.15)$ to increase starch digestibility, the increase was not as great as expected based on improvements observed for corn silage. For example, Weiss and Wyatt (2000) reported that processing corn silage increased digestibility of total dietary starch by 4.4 percentage units (93.2 vs. $97.6 \%$ for unprocessed vs. processed corn silage, respectively). With advancing maturity, barley grain kernels harden and develop complex matrices that can reduce starch digestion. It appears that mechanical processing of barley silage did not sufficiently disrupt kernel integrity to increase starch digestion.

Digestibility of starch observed in the present study is in general agreement with previous reports (Yang et al., 1997, 2000, and 2001). In contrast, digestibilities of NDF and ADF in our study were considerably lower than those published for studies in which barley silage was fed as the main forage source. The lower fiber digestion may have resulted from a reduction in the numbers of fibrolytic bacteria caused by a shift from fibrous to nonfibrous carbohydrate fermentation. The high grain content of the barley crop together with the relatively high concentrate proportion in the diet may have contributed to this microbial shift. Mertens et al. (2003) suggested a significant negative effect of the ratio of starch to NDF intake on fiber digestibility, which is not supported by our results. However, the low NDF digestibility in this study may have minimized the negative effects of high starch to NDF intake ratio on NDF digestibility.

Milk production averaged $33.9 \mathrm{~kg} / \mathrm{d}$ between treatments (Table 5), and was not affected by feeding the MPBS-TMR. Furthermore, neither milk composition nor milk component yield was influenced by feeding the MPBS-TMR. However, milk fat concentration was numerically $(P=0.32)$ higher for cows consuming the MPBS-TMR, which resulted in a numerical $(P=0.51)$ increase in FCM production. Differences in milk fat and 


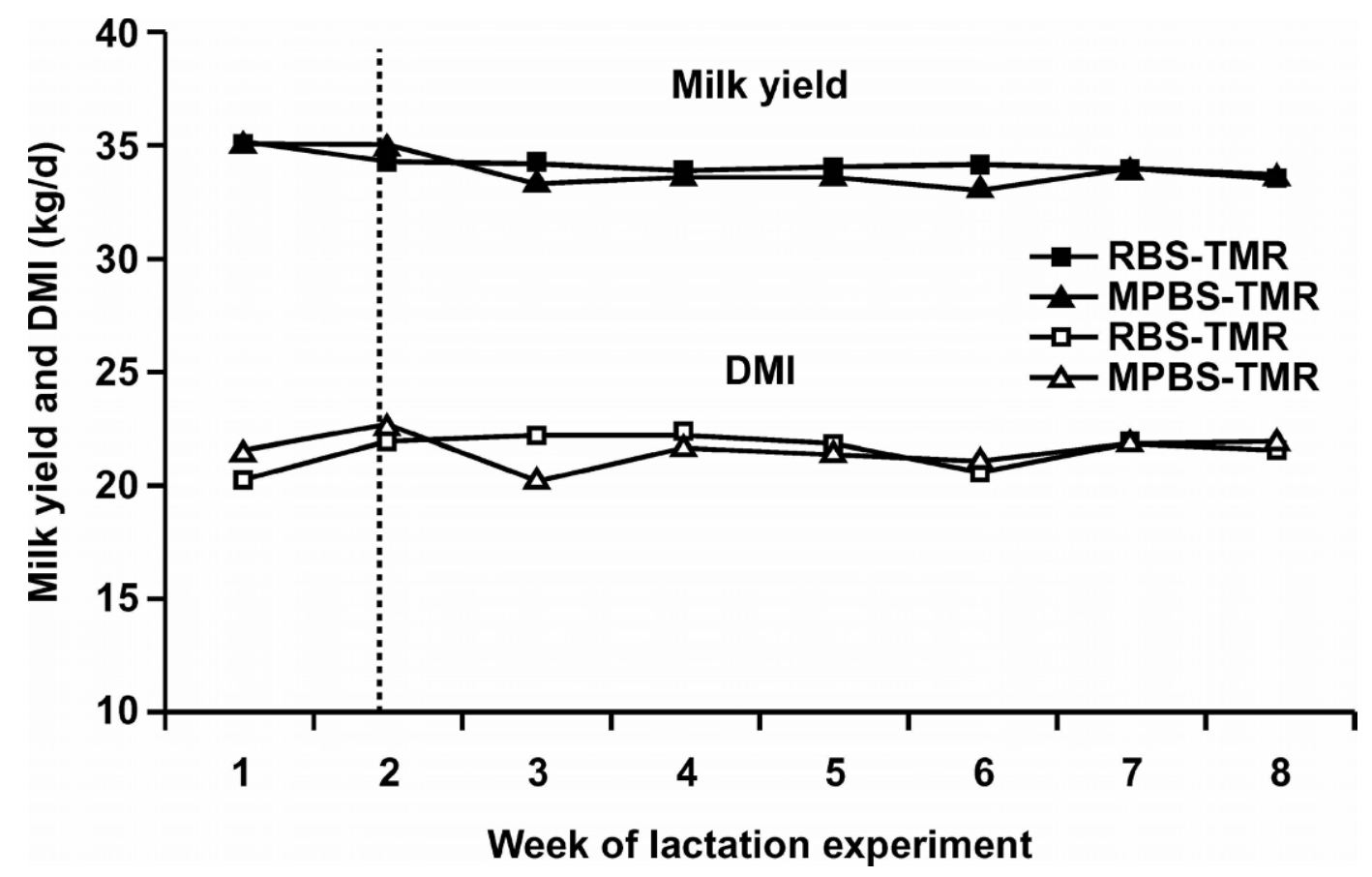

Figure 1. Dry matter intake and milk yield of dairy cows analyzed with covariate adjustment (response during first 2 wk of experiment). Treatments were TMR containing regular barley silage (RBS-TMR) and TMR containing mechanically processed barley silage (MPBS-TMR). Each point represents the mean of 12 observations ( $\mathrm{SE}=0.5$ and 0.6 for DMI and milk yield, respectively).

Table 5. Milk production, milk composition, and dairy efficiency by dairy cows fed regular or mechanically processed barley silage.

\begin{tabular}{|c|c|c|c|c|}
\hline \multirow[b]{2}{*}{ Item } & \multicolumn{2}{|c|}{ Diets $^{1}$} & \multirow[b]{2}{*}{$\mathrm{SE}$} & \multirow[b]{2}{*}{$P$} \\
\hline & RBS-TMR & MPBS-TMR & & \\
\hline \multicolumn{5}{|l|}{ Milk production, ${ }^{2} \mathrm{~kg} / \mathrm{d}$} \\
\hline Actual & 34.0 & 33.7 & 0.5 & 0.67 \\
\hline $4 \% \mathrm{FCM}$ & 29.7 & 31.7 & 2.2 & 0.51 \\
\hline \multicolumn{5}{|l|}{ Milk composition, \% } \\
\hline Fat & 3.30 & 3.57 & 0.19 & 0.32 \\
\hline Protein & 3.30 & 3.39 & 0.10 & 0.53 \\
\hline Lactose & 4.68 & 4.66 & 0.05 & 0.71 \\
\hline \multicolumn{5}{|c|}{ Milk component yield, $\mathrm{kg} / \mathrm{d}$} \\
\hline Fat & 1.08 & 1.18 & 0.07 & 0.32 \\
\hline Protein & 1.10 & 1.13 & 0.06 & 0.71 \\
\hline Lactose & 1.58 & 1.58 & 0.11 & 0.99 \\
\hline \multicolumn{5}{|l|}{ Dairy efficiency } \\
\hline Milk/DMI & 1.57 & 1.56 & 0.11 & 0.95 \\
\hline FCM/DMI & 1.39 & 1.45 & 0.09 & 0.62 \\
\hline Milk N/N intake & 0.27 & 0.27 & 0.01 & 0.99 \\
\hline \multicolumn{5}{|l|}{$\mathrm{BW}^{3}$} \\
\hline $\mathrm{kg}$ & 641 & 662 & 17 & 0.38 \\
\hline Change in BW, kg/d & 0.19 & 0.12 & 0.26 & 0.86 \\
\hline $\mathrm{BCS}^{4}$ & 2.82 & 2.92 & 0.08 & 0.34 \\
\hline
\end{tabular}

${ }^{1}$ RBS-TMR = TMR containing regular barley silage; MPBS-TMR = TMR containing mechanically processed barley silage.

${ }^{2}$ Yield of milk and $4 \%$ FCM during first 2 wk of lactation were used as covariates in the analysis.

${ }^{3}$ Data of BW and BCS during first 2 wk of lactation were used as covariates in the analysis.

${ }^{4}$ Scale used for scoring body condition was 5 -point scale, where $1=$ emaciated and 5 = overly fat (Wildman et al., 1982).
FCM were only trends and not statistically significant because of the large variation associated with means. This variation indicates that not all cows responded in the same manner to the effects of mechanical processing of barely silage. It is possible that this variability would have been reduced had only multiparous cows been used in the study.

Feeding the MPBS-TMR diet did not affect dairy efficiencies expressed as milk or FCM production corrected for DMI (Table 5). In spite of low fiber digestibility, the dairy efficiency in this study fell within the recommended range (Hutjens, 2002). The efficiency of $\mathrm{N}$ use, assessed as kilograms of milk $\mathrm{N}$ per kilogram of $\mathrm{N}$ intake, averaged 0.27 across treatments, and was not affected by feeding MPBS-TMR. Neither BW nor BCS differed between the treatments.

Determination of the effect of mechanical processing on in situ degradability requires that samples should not be dried or ground before in situ measurement to maintain potential treatment effects (Johnson et al., 1999). Because we ground the samples for in situ measurement of degradability, we did not expect any effect of mechanical processing of barley silage on in situ degradability. However, mechanical processing increased the soluble fraction, but decreased ruminal degradation rate of barley silage (Table 6). In contrast, ERD of DM was similar for RBS and MPBS, indicating that when the silages were ground to remove the effects of mechan- 
Table 6. Kinetics of in situ ruminal DM degradation of barley silages and TMR by dairy cows.

\begin{tabular}{lcccc}
\hline & \multicolumn{3}{c}{ Parameters $^{1}$} \\
\cline { 2 - 4 } Feeds $^{2}$ & $\mathrm{a}, \%$ & $\mathrm{~b}, \%$ & $\mathrm{c}, \% / \mathrm{h}$ & ERD, $\%$ \\
\hline Barley silage & & & & \\
RBS & $52.6^{\mathrm{e}}$ & 24.7 & $2.33^{\mathrm{d}}$ & 63.8 \\
MPBS & $55.5^{\mathrm{d}}$ & 26.8 & $1.27^{\mathrm{e}}$ & 63.8 \\
SE & 0.4 & 0.8 & 0.15 & 0.5 \\
TMR & & & & \\
RBS-TMR & 42.7 & 36.7 & $5.48^{\mathrm{d}}$ & 63.9 \\
MPBS-TMR & 44.8 & 36.4 & $4.84^{\mathrm{e}}$ & 64.7 \\
SE & 0.8 & 0.7 & 0.09 & 0.6 \\
\hline
\end{tabular}

${ }^{\mathrm{d}, \mathrm{e}}$ Within a column and feed, means that do not have a common superscript differ $(P<0.05)$.

${ }^{1}$ Parameters were calculated from the fitted equation: $\mathrm{P}=\mathrm{a}+\mathrm{b}(1-$ $\mathrm{e}^{-\mathrm{c}[\mathrm{t}-\mathrm{L}]}$ ) for $\mathrm{t}>\mathrm{L}$, where $\mathrm{P}=$ percentage of $\mathrm{DM}$ degradation from the bag at time $t, a=$ soluble fraction, $b=$ slowly degradable fraction, $\mathrm{c}=$ rate at which $\mathrm{b}$ is degraded, $\mathrm{L}=\mathrm{lag}$ time $(\mathrm{h})$, and $\mathrm{t}=$ time of incubation (h) . Effective ruminal degradability (ERD) was calculated using equation: $\mathrm{a}+\mathrm{bc} /(\mathrm{c}+\mathrm{k}$ ), where $\mathrm{k}=$ passage rate (assumed to be 2.8 and $4.0 \% / \mathrm{h}$ for barley silage and TMR, respectively).

${ }^{2} \mathrm{RBS}=$ Regular barley silage; MPBS = mechanically processed barley silage; RBS-TMR = TMR containing regular barley silage; MPBS-TMR = TMR containing mechanically processed barley silage.

ical processing, the potential digestion was similar for both silages. In contrast to previous findings (Yang et al., 2000; 2001), the soluble fractions of the barley silages were considerably higher and the slowly degradable fractions lower than those reported in the literature, resulting in higher ERD. This result further confirms that the barley silages used in this study had higher grain content with concomitant reduction of fiber content, resulting in the greater ERD and lower fiber digestibility.

For the TMR, neither the soluble fraction nor the potential degradable fraction differed between the RBSTMR and MPBS-TMR. However, ruminal degradation rate was higher for the RBS-TMR than the MPBS-TMR. Again, ERD did not differ between the treatments, and was similar between the barley silages and the TMR. Patterns of DM disappearance in situ were similar between silages and TMR throughout the total incubation time. From the beginning to $6 \mathrm{~h}$ of incubation, DM disappearance was higher for silages than TMR, but after $9 \mathrm{~h}$ of incubation, DM disappearance of TMR was higher than that of silages.

Higher disappearances of NDF and ADF for RBS than for MPBS were observed at $48 \mathrm{~h}$ of incubation in situ (Table 7), but they did not differ when incubated as a TMR for $48 \mathrm{~h}$. Similarly, Johnson et al. (2003) reported (for silages with short chop length of $0.95 \mathrm{~cm}$ ), that NDF disappearance was greater for unprocessed corn silage than for processed corn silage measured at 24 and $48 \mathrm{~h}$ of incubation in the rumen. Because samples for in situ measurement were ground, it is not clear
Table 7. In situ ruminal fiber disappearance of barley silages and TMR by dairy cows.

\begin{tabular}{lrrrr}
\hline & \multicolumn{4}{c}{ In situ disappearance, \% } \\
\cline { 2 - 3 } & \multicolumn{2}{c}{ NDF } & & ADF \\
\cline { 2 - 3 } \cline { 5 - 6 } Feeds $^{1}$ & $24 \mathrm{~h}$ & $48 \mathrm{~h}$ & $24 \mathrm{~h}$ & $48 \mathrm{~h}$ \\
\hline Barley silage & & & & \\
RBS & 13.5 & $38.8^{\mathrm{a}}$ & 12.6 & $40.4^{\mathrm{a}}$ \\
MPBS & 11.7 & $27.8^{\mathrm{b}}$ & 10.9 & $29.0^{\mathrm{b}}$ \\
SE & 1.3 & 2.1 & 1.3 & 2.2 \\
TMR & & & & \\
RBS-TMR & 17.6 & 38.5 & $16.5^{\mathrm{a}}$ & 38.0 \\
MPBS-TMR & 16.2 & 39.0 & $8.9^{\mathrm{b}}$ & 34.6 \\
SE & 1.7 & 2.0 & 1.9 & 2.1 \\
\hline
\end{tabular}

${ }^{\mathrm{a}, \mathrm{b}}$ Within a column and feed, means that do not have a common superscript differ $(P<0.05)$.

${ }^{1} \mathrm{RBS}=$ Regular barley silage; MPBS = mechanically processed barley silage; RBS-TMR = TMR containing regular barley silage; MPBS-TMR = TMR containing mechanically processed barley silage.

whether mechanical processing damaged the barley stem tissue sufficiently and increased fiber degradation. Given the similar in vivo fiber digestibility between treatments, however, it appears that mechanical processing did not sufficiently damage the fiber fraction of barley silage. We speculate that the lack of response to processing was likely caused by the conditions of the mechanical processing. In order for mechanical processing to be effective for barley silage, processing conditions should be modified from the ones used for corn silage. Alternatively, mechanical processing may be a more effective means of improving digestibility for barley silage harvested in a more advanced stage of maturity than the mid-dough stage used in this study.

\section{CONCLUSIONS}

Mechanical processing did not cause chemical changes to the barley silage used in this study; only slight changes in physical characteristics due to processing were observed. Feeding MPBS did not improve use of nutrients by dairy cows in midlactation. There were only numerical increases in starch digestion, milk fat concentration, and FCM yield. The mechanical processing conditions used for barley silage in our study were similar to the ones typically used for processing corn silage. Because the size and structure of grain kernel from corn and barley are quite different, the rollers designed for processing corn silage are unsuitable for processing barley silage.

\section{ACKNOWLEDGMENTS}

The authors wish to thank the crew at the Dairy Research Unit of the Lethbridge Research Centre for caring for the cows and milk sample collection. Assis- 
tance provided by B. Farr, K. Andrews, and R. Wuerfel during the collection period and sample analysis is sincerely appreciated.

\section{REFERENCES}

Association of Official Analytical Chemists. 1990. Official Methods of Analysis. AOAC, Arlington, VA.

Bal, M. A., R. D. Shaver, A. G. Jirovec, K. J. Shinners, and J. G. Coors. 2000. Crop processing and chop length of corn silage: Effects on intake, digestion, and milk production by dairy cows. J. Dairy Sci. 83:1264-1273.

Baron, V. S., A. C. Dick, and M. S. Wolynetz. 1992. Characterization of barley silage-maturity relationships for central Alberta. Can. J. Plant Sci. 72:1009-1020.

Baron, V. S., E. Okine, and A. C. Dick. 2000. Optimizing yield and quality of cereal silage. Pages 351-367 in Proc. of the Western Canadian Dairy Seminar, Univ. Alberta, Edmonton, AB, Canada.

Hutjens, M. 2002. Using dairy efficiency. Online. Available: http:// www.traill.uiuc.edu/dairynet/paperDisplay.cfm?Type= currentTopic\&ContentID=612. Accessed June 18, 2004.

Johnson, L., J. H. Harrison, C. Hunt, K. Shinners, C. G. Doggett, and D. Sapienza. 1999. Nutritive value of corn silage as affected by maturity and mechanical processing: A contemporary review. J. Dairy Sci. 82:2813-2825.

Johnson, L. M., J. H. Harrison, D. Davidson, C. Hunt, W. C. Mahanna, and K. Shinners. 2003. Corn silage management: Effects of hybrid, maturity, chop length, and mechanical processing on rate and extent of digestion. J. Dairy Sci. 86:3271-3299.

Johnson, L. M., J. H. Harrison, D. Davidson, M. Swift, B. Mahanna, and K. Shinners. 2002. Corn silage management II: Effects of hybrid, maturity, and mechanical processing on digestion and energy content. J. Dairy Sci. 85:2913-2927.

Khorasani, G. R., E. K. Okine, J. J. Kennelly, and J. H. Helm. 1993. Effect of whole crop cereal grain silage substituted for alfalfa silage on performance of lactating dairy cows. J. Dairy Sci. 76:3536-3546.

Lammers, B. P., D. R. Buckmaster, and A. J. Heinrichs. 1996. A simple method for the analysis of particle sizes of forage and total mixed rations. J. Dairy Sci. 79:922-928.
Mertens, D. R., G. Ferreira, P. Berzaghi, and R. D. Shaver. 2003. Corn silage maturity and processing: 2 . Effects on fiber and starch digestion by dairy cows. Pages $86-87$ in U.S. Dairy Forage Research Center 2002 Research Report. ARS-USDA, Madison, WI.

Mustafa, A. F., D. A. Christensen, and J. J. McKinnon. 2000. Effects of pea, barley, and alfalfa silage on ruminal nutrient degradability and performance of dairy cows. J. Dairy Sci. 83:2859-2865.

Ørskov, E. R., and I. McDonald. 1970. The estimation of protein degradability in the rumen from incubation measurements weighted according to rate of passage. J. Agric. Sci. (Camb.) 92:499-503.

Rode, L. M., W. Z. Yang, and K. A. Beauchemin. 1999. Fibrolytic enzyme supplementations for dairy cows in early lactation. J. Dairy Sci. 82:2121-2126.

SAS Institute. 2001. SAS/STAT Users Guide (Release 8.0). SAS Inst., Inc., Cary, NC.

Sniffen, C. J., J. D. O'Connor, P. J. Van Soest, D. G. Fox, and J. B. Russell. 1992. A net carbohydrate and protein system for evaluating cattle diets: II. Carbohydrate and protein availability. J. Anim. Sci. 70:3562-3577.

Weiss, W. P., and D. J. Wyatt. 2000. Effect of oil content and kernel processing of corn silage on digestibility and milk production by dairy cows. J. Dairy Sci. 83:351-358.

Wildman, E. E., G. M. Jones, P. E. Wagner, R. L. Boman, H. F. Troutt, Jr., and T. N. Lesch. 1982. A dairy body condition scoring system and its relationship to selected production characteristics. J. Dairy Sci. 65:495-501.

Williams, C. H., D. J. David, and O. Ilsmaa. 1962. The determination of chromic oxide in faeces samples by atomic absorption spectrophotometry. J. Agric. Sci. (Camb.) 59:381-385.

Yang, W. Z., K. A. Beauchemin, B. I. Farr, and L. M. Rode. 1997. Comparison of barley, hull-less barley, and corn in the concentrate of dairy cows. J. Dairy Sci. 80:2885-2895.

Yang, W. Z., K. A. Beauchemin, and L. M. Rode. 2000. Effects of barley grain processing on extent of digestion and milk production on lactating cows. J. Dairy Sci. 83:554-568.

Yang, W. Z., K. A. Beauchemin, and L. M. Rode. 2001. Effects of grain processing, forage to concentrate ratio, and forage particle size on rumen $\mathrm{pH}$ and digestion by dairy cows. J. Dairy Sci. 84:2203-2216. 